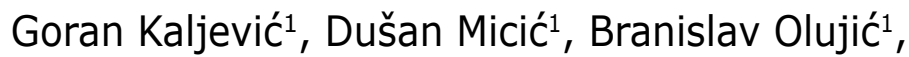
Ivan Stoimirov ${ }^{2}$, Zlatibor Lončar ${ }^{1}$

\title{
INTERHOSPITALNI TRANSPORT KRITIČNO OBOLELIH I TEŠKO POVREĐENIH PACIJENATA
}

\begin{abstract}
Sažetak: Sekundarni (interhospitalni) transport kritično obolelih i povređenih je uvek aktuelno pitanje, za koje postoji značajno interesovanje. Interhospitalni transport u veći urgentni centar mora biti indikovan brzo po prispeću pacijenta u inicijalni centar/bolnicu da bi se što manje odlagalo definitivno zbrinjavanje. Indikacije za prevođenje u centar višeg nivoa zasnivaju se na: vrednostima vitalnih parametara, prisustvo specifičnih povreda ili patofizioloških stanja, moguće pogoršanje zbog mehanizma povrede i komorbidnih faktora ili proceni da je pacijent $u$ visokom riziku. Svrha vodiča i protokola je da pomognu ranom zbrinjavanju i lečenju specifičnih povreda koje ugrožavaju pacijenta, kao što su: spinalna trauma, povrede glave i CNS-a, opekotine, trudnice i trauma dece. Sekundarni transport treba indikovati samo kada on obezbeđuje mogućnosti boljeg lečenja i ishoda. Treba ga obaviti na način koji ne ugrožava nivo i kvalitet potrebne nege. Rano prepoznavanje kritične bolesti ili ugrožavajuće povrede koje zahteva interhospitalni transfer mora biti utvrđeno upotrebom trijažnih vodiča. Pacijenti sa ugrožavajućim mehanizmom povrede i komorbiditetima u riziku su od razvoja sistemskih komplikacija. Hemodinamska stabilnost $\mathrm{u}$ toku transporta zahteva pažljivu pripremu u inicijalnoj ustanovi. Dobra komunikacija između inicijalne i sekundarne ustanove, kao i uigranost osoblja su neophodni. Urgentna medicina ima odlučujuću ulogu u organizaciji i sprovođenju sekundarnog transporta.
\end{abstract}

Ključne reči: sekundarni transport, kritična oboljenja, teška trauma, razlozi za transport, trijaža

Sekundarni (interhospitalni) transport kritično obolelih i povređenih je uvek aktuelno pitanje, za koje postoji značajno interesovanje. Pacijenti visokog rizika koji zahtevaju transfer na velike udaljenosti prevode se uglavnom u centre višeg nivoa zbog intenzivnog lečenja. Najveći broj ovih pacijenata prevezu službe hitne medicinske

1 Goran Kaljević, Klinika za urgentnu hirurgiju, Centar za zbrinjavanje urgentnih stanja, Klinički centar Srbije.

Centar za anesteziologiju i reanimatologiju, Klinički centar Srbije. 
pomoći. Neophodno je da specijalisti urgentne medicine, koji sprovode transport, i kliničari, koji šalju/primaju pacijenta, budu upućeni u protokole primopredaje i zbrinjavanja teških bolesnika. Ova saradnja bi trebalo da uključi uvažavanje lokalnih i regionalnih organizacionih okvira za ovu grupu pacijenata. ${ }^{1}$

Interhospitalni transfer u veći urgentni ili trauma centar treba indikovati što pre po prijemu da bi se izbeglo odlaganje potrebne intenzivne nege i intervencija. Značajna većina kritičnih pacijenata koji su bili definitivno zbrinuti u centru odgovarajućeg nivoa imaju manji morbiditet $\mathrm{i}$ bolji ishod.

Indikacije za prevođenje kritično obolelog ili teško povređenog u centar višeg nivoa treba da se zasnivaju na vrednostima vitalnih znakova, prisustvu specifičnih povreda i stanja, visokorizičnom mehanizmu povrede ili proceni da je pacijent $u$ visokom riziku. ${ }^{2}$ Cilj vodiča i protokola je podržavanje ranog indikovanog transporta zbog pravovremenog zbrinjavanja grupe pacijenata sa specifičnim povredama kao što su povrede kičme, opekotinska bolest i velike opekotine, povrede mozga, trauma trudnica i dece. Ovi vodiči treba da proizađu kao rezultat kolaboracije eksperata relevantnih specijalnosti.

Transport pacijenata deli se u nekoliko nivoa. Primarni (prehospitalni) transport predstavlja transport od mesta udesa ili obolevanja do prve izabrane bolnice. Sekundarni transport je transport pacijenta iz prve hospitalne ustanove, gde je primljen/zbrinut, u sledeću, obično radi unapređenja lečenja; intrahospitalni transport dešava se unutar iste ustanove, npr. transport sa jednog na drugo odeljenje (sa urgentnog prijema u jedinicu intenzivnog lečenja). Rizici i opasnosti, kao i potrebna nega koju intrahospitalni transport nosi i zahteva praktično su isti kao i u sekundarnom transportu. ${ }^{3}$

\section{Indikacije za sekundarni transport}

Sekundarni transport opravdan je samo ako doprinosi unapređenju nege pacijenta i poboljšanju ishoda ${ }^{1-3}$. Mora se organizovati i obaviti na način koji ne ugrožava nivo i kvalitet nege.

\section{Osoblje koje prati pacijenta}

U našoj zemlji preko $95 \%$ svih sekundarnih transporta obave službe hitne medicinske pomoći u pratnji odgovarajućeg specijaliste ${ }^{3}$ (obično specijaliste urgentne medicine) $i$ adekvatno obučenih $i$ iskusnih sestara/tehničara.

Podaci iz literature ${ }^{4}$ potvrđuju da je kvalitet nege najbolji ako transport sprovodi ovakav tim $^{1-3}$.

Za sada, međutim, nije dokazano da li na uspešan sekundarni transport više utiče oprema i iskustvo, znanje i uigranost transportnog tima ili dobra stabilizacija u prvoj ustanovi, odakle se pacijent transportuje. ${ }^{3}$ 
Sastav i profil tima koji treba da prati pacijenta u sekundarnom transportu, a inače nije transportni tim, za sada nije jasno utvrđen. Svakako, njega treba da čine bar jedan stariji specijalista-anesteziolog i jedna iskusna sestra iz jedinice intenzivnog lečenja ${ }^{3,4}$.

Tabela 1. Razlozi za sekundarni transport ${ }^{5}$

\begin{tabular}{|l|l|}
\hline Razlog sekundarnog transporta & \multicolumn{1}{c|}{ Objašnjenje } \\
\hline Ne postoji mogućnost za intenzivno lečenje & Seoska sredina, privatne zdravstvene ustanove \\
\hline Dijagnostika & $\begin{array}{l}\text { Potreba za specijalističkom evaluacijom i dijagnostičkom opremom (npr. } \\
\text { angiografija), ustanova nema resurse }\end{array}$ \\
\hline Nemogućnost optimalne kliničke evaluacije & $\begin{array}{l}\text { Ne može se obaviti zbog odsustva pojedinih specijalista/osoblja } \\
\text { (vaskularni hirurg, neurohirurg) itd. }\end{array}$ \\
\hline Specijalisti, oprema & Nemogućnost izvođenja određenih intervencija \\
\hline Premeštanje, vraćanje bolesnika & $\begin{array}{l}\text { Mogu postojati lokalni, regionalni ili internacionalni razlozi, bilo da je } \\
\text { pacijent prvobitno preveden iz ustanove u svojoj sredini ili da mu se } \\
\text { bolest/povreda dogodila na udaljenom mestu. }\end{array}$ \\
\hline Ostali (neklinički) razlozi & $\begin{array}{l}\text { Nedostatak mesta na odgovarajućem odeljenju, obično intenzivnog } \\
\text { lečenja }\end{array}$ \\
\hline
\end{tabular}

\section{Klinički imperativ}

Rana identifikacija kritičnog stanja ili multiple i opsežne trauma, što zahteva interhospitalni transfer, moraju biti obavljeni upotrebom definisanog trijažnog vodiča!

\section{Identifikovanje potencijalno teške traume}

Izmenjeni vitalni znaci

Izolovana povreda glave kod starijih

Penetrantne povrede (osim izolovanih i površnih otvorenih povreda ekstremiteta)

\section{Specifične povrede}

Amputacija ili preteća amputacija ekstremiteta, ozbiljna kraš-povreda, kompletne frakture dugih kostiju, otvorene frakture, frakture sa dislokacijom, dve ili više fraktura femura, tibije, humerusa, fraktura karlice. 


\section{Opekotine}

Opekotina koja zahvata više od $20 \%$ površine kože kod odraslog ili $10 \%$ kod deteta; sumnja na opekotinu disajnih puteva i udisanje dima.

Udar struje visoke voltaže

Povreda mozga i glave

Neurološki deficit, prelom lobanje, patološki nalaz na CT

\section{Povreda kičme}

Značajna povreda kičme, bilo kakva (i minimalna) povreda kičmene moždine i spinalnih nerava, neurološki deficit

\section{Trauma dece}

\section{Trauma trudnica}

Distres ploda, fetus ispod 24. gestacione nedelje, moguća povreda uterusa ${ }^{3-6}$

\section{Pacijenti visokog rizika}

Pacijenti visokog rizika su oni sa etiološkim mehanizmom koji ukazuje na teške povrede, $\mathrm{i} / \mathrm{ili}$ komorbiditetom sumnjivim na pojavu teških sistemskih komplikacija. Ovi pacijenti, sa stabilnim hemodinamskim statusom, treba da prođu kompletnu dijagnostiku i da budu opservirani neko vreme. Ako je pacijent sve vreme stabilan, a faktori rizika su samo mehanizam povrede ili komorbiditet, postoji mogućnost da bude nepotrebno klasifikovan u višu trijažnu kategoriju, ako nije opserviran i pravilno trijažiran. Ako se stanje takvog pacijenta pogoršava, treba razmotriti potrebu transporta u centar višeg nivoa. Faktori visokorizični za tešku traumu su: ispadanje iz vozila, motociklista i biciklista koji učestvuju u udesu (brzina vozila sa kojim se sudario veća od $30 \mathrm{~km} / \mathrm{sat}$ ), pad sa visine veće od $3 \mathrm{~m}$, eksplozija. saobraćajni udes pri brzinama većim od $60 \mathrm{~km} / \mathrm{sat}$, povreda pešaka u saobraćajnom udesu, uzrasta mlađeg od 10 i starijeg od 55 godina, trudnoća, značajan komorbiditet. ${ }^{7}$

\section{Faktori koji utiču na način transporta}

1. Priroda bolesti/povrede

2. Hitnost transporta 
3. Dostupnost transportnog sredstva

4. Vreme transporta

5. Geografski faktori

6. Vremenske prilike i stanje na putu

7. Odnos troškova i kvaliteta transporta

\section{Nega pre sekundarnog transporta}

Svaki transport zahteva da pacijent bude hemodinamski maksimalno stabilan, radi poboljšanja ishoda. ${ }^{3,5,8}$ Održavanje stabilnosti u toku transporta ${ }^{8}$ zahteva pažljivu obradu i stabilizaciju pacijenta pre transporta, u ustanovi u koju je prvobitno primljen. ${ }^{9}$ Previđanje ili potcenjivanje povreda, kao i zanemarivanje kardiorespiratorne nestabilnosti, neplaniranje potencijalnih pogoršanja ili događanja u toku transporta mogu ugroziti ishod lečenja. ${ }^{4-6}$

Pacijenti koji zahtevaju intenzivnu životnu potporu ili reanimaciju na sekundarnom prijemu verovatno će imati lošiju prognozu..$^{3-6}$

\section{Razmatranje događanja u toku transporta}

Ako su adekvatne mere stabilizacije bile preduzete pre transporta, ne bi trebalo da postoji potreba za intervencijama $u$ toku transporta. Obavezna je kontinuirana evaluacija stanja pacijenta. Venski putevi za nadoknadu moraju se proveravati i biti prohodni. Idealno bi bilo da nivo monitoringa i učestalost praćenja vitalnih parametara budu isti (ili bar slični) kao i u odgovarajućoj ustanovi.

Neželjeni događaji u toku transporta moraju biti evidentirani i mere/intervencije za nihovo sprečavanje sprovedene što je moguće ekspeditivnije.

Upotreba rotacionog svetla, sirene i policijske pratnje treba da bude maksimalno redukovana za neophodne situacije i ove mere ne treba da se preduzimaju rutinski.

Vrlo je značajna i dokazano korisna dobra komunikacija između osoblja koji šalje i onog koje prima pacijenta. ${ }^{6,1}$ Mnogi autori su publikovali liste stanja pacijenta koje se šalju kao dokumentacija iz ustanove koja ga upućuje, liste stanja u toku transporta i primopredajne liste. Ove liste sadrže sve neophodne kliničke parametre u toku praćenja pacijenta od prijema u prvu, do prijema u sekundarnu ustanovu. Prijemna ustanova mora da bude obaveštena ako se planirano vreme stizanja ili stanje pacijenta bitnije promeni. Prijemna ustanova se obaveštava na početku transporta i 10 min. pre stizanja. Pacijent i porodica moraju o svemu da budu informisani sve vreme. Nije rutinski običaj da član porodice putuje sa pacijentom.

Urgentna medicina ima ključnu ulogu u organizaciji sekundarnog transporta. Tradicionalno, postoji i dalje tendencija da se transfer pacijenata vrši u ad hoc mani- 
ru. To je rezultat različite prakse i standarda za proces transporta. Postojanje vodiča i protokola nivoa nege i načina transporta i postupaka u toku sekundarnog transfera doprinose boljem ishodu. ${ }^{7-9}$

\section{Literatura}

1. Fitzharris M, Stevenson M, Middleton P, Sinclair G. Adherence with the pre-hospital protocol in the transport of injured patients in an urban setting. Injury, 43(2012): 1368-1376.

2. American College of Surgeons. Advanced Trauma Life Support. 10th edition. American College of Surgeons, Chicago, 2016.

3. Whitely S, Macartney I, Mark J, Barratt H, Binks R. Guidelines for the transport of the critically ill adult. 3rd edition. 2011 Intensive Care Society, UK.

4. Victorian State Trauma Registry Special Focus Report. Review of the Case Review Group Indicators - Addendum to Report. April 14, 2014. VSTORM.

5. Faculty of Intensive Care of the Australasian and New Zealand College of Anaesthetists, and Australian College of Emergency Medicine. Intra-hospital of critically ill patients. Melbourne: Australian and New Zealand College of Anaesthetists, 2000.

6. The Association of Anaesthetists of Great Britain and Ireland. Recommendations for standards of monitoring. London: The Association of Anaesthetists of Great Britain and Ireland, 2013.

7. Runcie CJ, Reeve WR, Wallace PGM. Preparation of the critically ill for interhospital transfer. Anaesthesia 2014; 47: 327-31.

8. Advanced Life Support Group. Safe transfer and retrieval. The practical approach. London: BMJ Books, 2012.

9. A Gray, S Bush, S Whiteley. Secondary transport of the critically ill and injured adult. Em Med J. 2016; (21)3: 281-285. 